\title{
Traditional medicinal plant knowledge of some spermatophytes of Samar Bagh Valley, Lower Dir district, Pakistan
}

\author{
Muhammad Irfan, ${ }^{* 1}$ Imran Ahmad ${ }^{2}$ and Sidra Hassan Saeed ${ }^{2}$ \\ ${ }^{1}$ Department of Botany, Abdulwali Khan University, Mardan, Pakistan \\ ${ }^{2}$ Department of Botany, Hazara University, Mansehra, Pakistan
}

Article history

Received: 27 August 2017

Accepted: 26 September 2017

Published: 01 October 2017

(c) Irfan et al. (2017)

Editor

Bhupinder Dhir

Publisher

Horizon e-Publishing Group

Correspondence

Muhammad Irfan

$\square$ mirfan310@yahoo.com

\begin{abstract}
The study on traditional knowledge of medicinal plants which are used by local people of Samar Bagh valley in district Lower Dir, Pakistan resulted in the report of 41 species of seed plants which belong to 37 genera and 30 families. Amongst them are 55\% herbs, $25 \%$ shrubs, $17 \%$ trees and 3\% rhizome bearing species. The local peoples who use these plants for the treatment of various diseases were farmers, those who are raring of live stock and hakims.
\end{abstract}

\section{Keywords}

Ethno-medicine; Lower Dir; Samar Bagh; Khyber Pakhtunkhwa; Pakistan.

\section{Citation}

Irfan M, Ahmad I, Saeed S H. Traditional medicinal plant knowledge of some spermatophytes of Samar Bagh Valley, Lower Dir district, Pakistan. Plant Science Today 2017;4(4):151-153. doi: 10.14719/pst.2017.4.4.334

\section{Introduction}

Samar Bagh is a secretarial subdivision of District Lower Dir Khyber Pakhtunkhwa province Pakistan. Its geographical coordinates are $34^{\circ}-37 /$ to $35^{\circ}-7$ / $\mathrm{N}$ Latitudes and $71^{\circ}-31$ / to $72^{\circ}-14$ / E longitudes. Samar Bagh valley starts from Kaaskoto extend up to Binshahi which is $35 \mathrm{~km}$ away from Timergara headquarter. District Lower Dir comprises of 1582 $\mathrm{sq} \mathrm{km}$ area and located in Malakand Division. Almost all of it lies in the valley of the Panjkora which raises high in the Hindu Kush and joins the Swat River near Chakdara. Samar Bagh is bounded by Swat district to the east, Bajour Agency to the west, Upper Dir to the north, and Malakand district to the south. Samar Bagh valley lies in the southern part of Hindukush Range having an altitude from 1200 to 2300 meters. The summer season is moderate and hot, June and July are hottest months and in June maximum and minimum temperature has been recorded as $32.52{ }^{\circ} \mathrm{C}$ and $15.67{ }^{\circ} \mathrm{C}$ respectively. The winter season is cold and the temperature rapidly decreases from November and onwards. December, January and February are the coldest months, during these months temperature fall below the $0{ }^{\circ} \mathrm{C}$. The maximum and minimum temperature during the month of January was recorded as $11.22{ }^{\circ} \mathrm{C}$ and $-2.39{ }^{\circ} \mathrm{C}$ respectively [1]. Due to the variation in altitude, rainfall, topographic and edaphic factors the vegetation of Samar Bagh valley is sub-tropical, temperate and up to some extent of alpine type. Oryza sativa, 


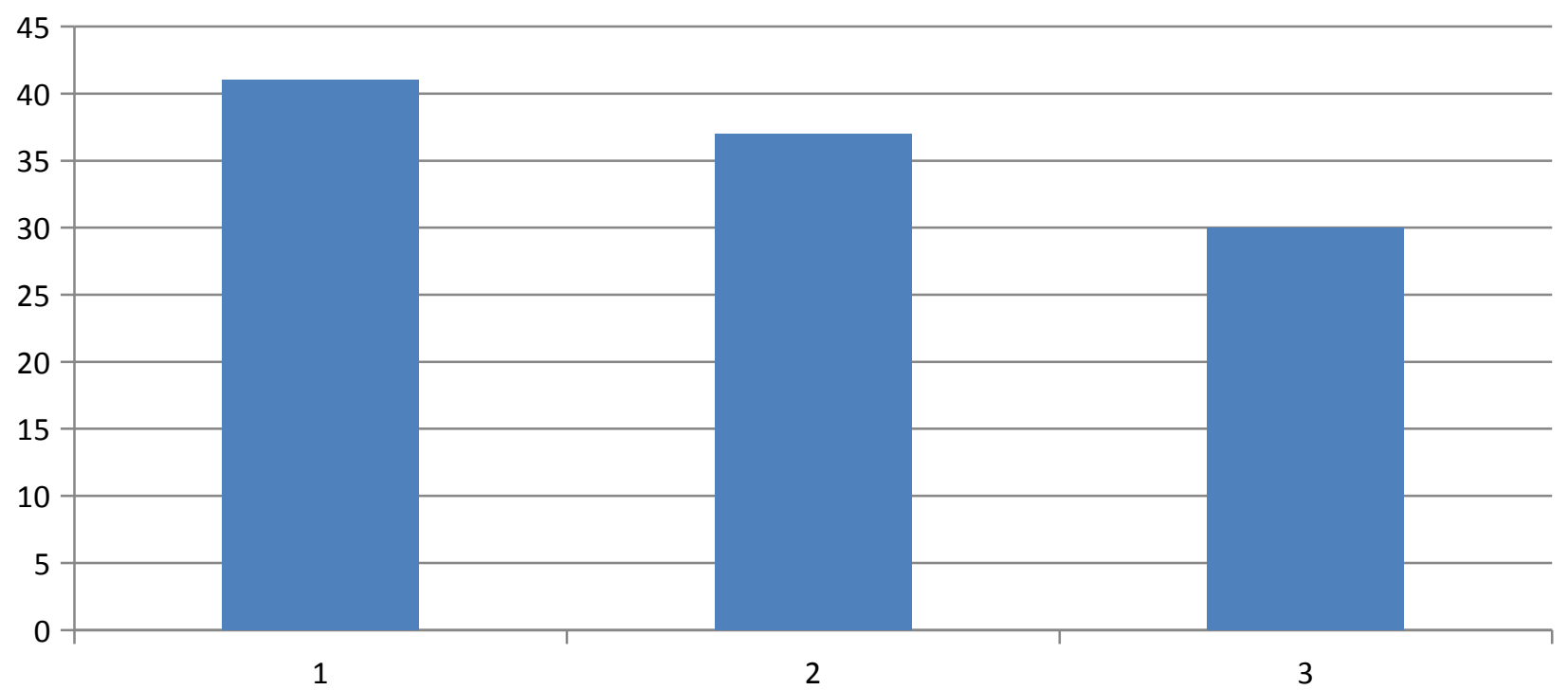

Fig. 1. Number of Families, genera and species with highest representation of ethno medicinal spermatophytes of Samar Bagh valley, district Lower Dir, Khyber Pakhtunkhwa, Pakistan

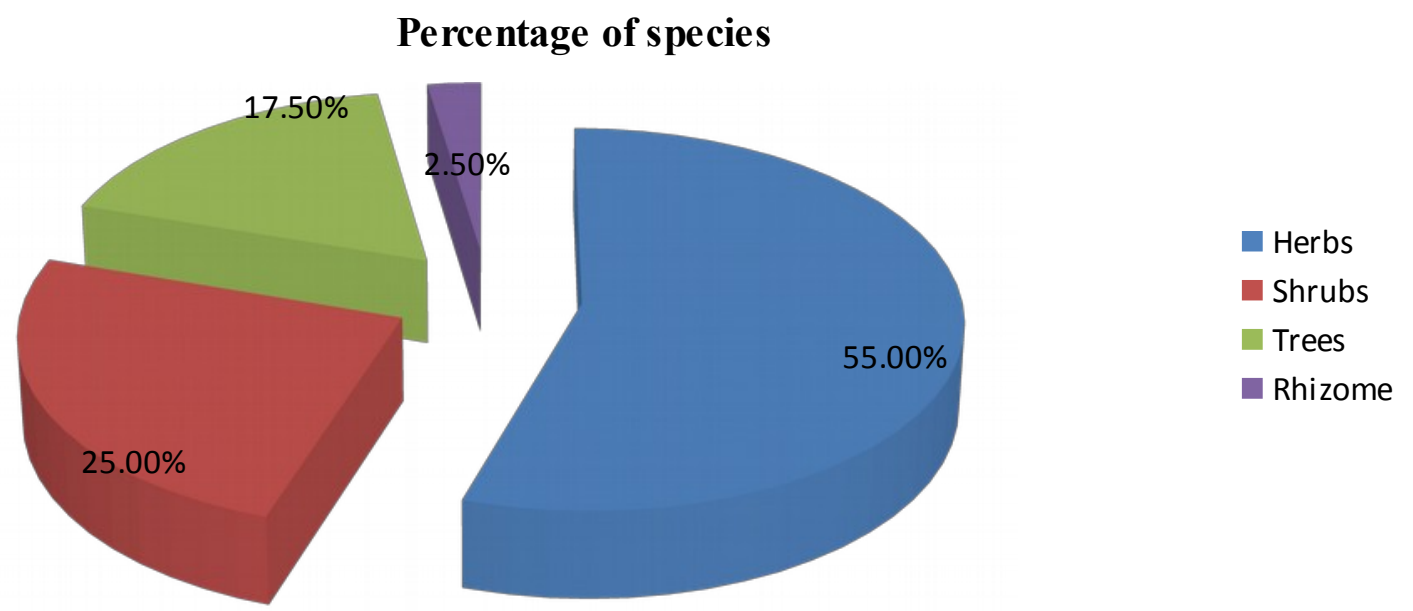

Fig. 2. Percentage wise uses of herbs, shrubs, trees and rhizome of ethno medicinal spermatophytes of Samar Bagh valley, district Lower Dir, Khyber Pakhtunkhwa, Pakistan

Triticum aestivum, Solanum nigrum, Allium sativa, Hibiscus esculentus, cucurbita maxima, Brassica napus, Cicer arietanum and phaselous vulgaris etc were the major crops and fruits viz. different species of Prunus, Pyrus pashia, Malus pumila and Diosporus kaki etc are cultivated. Amongst oil yielding crops, Helianthus annus and Brassica campestris is the most traditional crops. Amongst wild plants viz. Popular, Salix, platanus, Morus, Ailanthus altisema, Robinia pseudo acassia, Dodonaea viscosa, Olea ferruginea, Quercus dilatata, Pinus wallichiana, Alnus nitida, Aesculus indica, Juglans regia and Betula utilis are the common plants [2]. The area was selected for research to review old knowledge about plants uses because there was great scarcity of Doctor and Hakims in the past. Any plant which contain active bio-chemical constituent and gives a definite physiological response in the treatment of disease in humans and animals are known as medicinal plant [3]. More than $50 \%$ of all modern clinical or allopathic drugs are of natural product origin; hence traditional medicines can play a vital role in the pharmaceutical sciences [4]. Pakistan is bestowed with a great diversity of medicinal plants. Out of 6000 flowering plant species in Pakistan, 600 were reported for their medicinal uses. It is a fact that chemical and synthetic drugs have caused much harm to the human body through side effects [5]. Therefore, human now resorted to natural methods of treatment. The requirement for medicinal plants is increasing every day and the efforts are being made to get benefit from the old Tabibs belong to Tibb-I-Unani and the Ayurvedic Systems of Medicine [6]. These medicines have lesser side effects and man can get it easily from nature. Unani system is dominant in Pakistan but the ethno- medicine is being practiced in the remote areas [7]. 


\section{Materials and Method}

The collection of plant specimens were conducted during late spring 2016 in Samar Bagh Valley, district Lower Dir, Khyber Pakhtunkhwa, Pakistan. Plants specimens were collected from various localities viz., Mayar, Samar Bagh, Kaambat, Maidan, Gumbat baanda, Maskeni, Dalgraam, Shahi, Binshahi and Ghwara banda. The collected plants were tagged, pressed, dried in newspapers and preserved for identification. Plants were identified with help of available literature and the Flora of Pakistan [8] and [9]. Related information was gathered from the local peoples and hakeems viz., Gujars, Yousafzai, Mastkheils, Akakheils and Sultankheil through questionnaire and interviews due to which indigenous medicinal plant knowledge was documented.

\section{Results and Discussion}

Ethnomedicinal plants survey of various localities of tehsil Samar Bagh district Lower Dir; Khyber Pakhtunkhwa, Pakistan was carried out having 41 plants species of 37 genera in 30 families (Supplementary Table 1, Fig. 1). Amongst them are $55 \%$ herbs, 25\% shrubs, $17 \%$ trees and 3\% rhizome geophytes (Supplementary Table 1, Fig. 2) used by the local peoples for the treatment of various ailments. Asteraceae were the family offering four medicinal species followed by Lamiaceae and Lilaceae with three species. Amaranthaceae, Rhamnaceae, Rosaceae and Pinnaceae have two species each used for different disorders while the rest of families represented by a species (Supplementary Table 1). According to the data majority of the women and men were involved in collection of medicinal plants. Most of the population were involved in farming, agriculture and raring of live stock and were illiterate. Majority of the respondents had knowledge about the local names and their ethno medicinal uses. There is medicinal plant studies were conducted earlier from Dir Kohistan Upper Dir, Pakistan [10] from Chitral district Pakistan at Hindukush range [11] from Baluchistan province, Pakistan [12] at Shawar valley district Swat, Pakistan [13]. These reports indicate that most of the plants species were used for the treatment of infertility, hair fall, cough, ulcer, diabetes as a mouth wash etc.

\section{Conclusion}

The study suggests that residents of hilly and rural areas frequently used these taxa. Knowledge-wise elderly people have more awareness regarding the medicinal plants and their uses. Mostly the plant taxa were used against diseases like hepatitis, diabetes, infertility, skin problems, hair-care and tonics. These taxa may be explored utilized for new drugs and exploited commercially keeping in view of their availability and sustainable supply.
Cultivation of these taxa for food, medicine and ornamental purpose is highly needed.

\section{Author Contribution Statement}

MI conducted the experiment and carried out the statistical analysis, IA designed the experiment, and SHS structured and wrote the manuscript.

\section{Conflict of Interest}

The authors declare that they have no conflict of interest.

\section{Acknowledgements}

The authors are thankful to the local communities for sharing their medicinal plant knowledge.

\section{References}

1. Anonymous. District Census report of District Lower Dir, Bauru of Statistics government of Pakistan, Islamabad, Pakistan; 1998.

2. Sirajuddin. Plants and Plant Resources of Maidan Valley Dir Northern Pakistan. Ph.D. Thesis. Dept of Biological Sciences, QAU, Islamabad; 2007.

3. Ahmand H. The Medicinal plants of Tharparker, WWF-Pakistan Peshawar; 2000.

4. Williams J T, Ahmad Z. Priorities for medicinal plants research and development in Pakistan. South Asia Regional office IDRC, Canada medicinal and aromatic plants program in Asia (MAPPA), New Delhi, India; 1999.

5. Ali S I, Qaiser M. A phytogeographical analysis of the Phanerogams of Pakistan and Kashmir. Proc. R. Soc. Edinburg 1986;89:89-101. doi: 10.1017/S0269727000008939

6. Wazir S M, Dasti A A, Shah J. Common medicinal plants of Chapursan valley, Gojal II, GilgitPakistan.J. Res (Science) Bahauddin Zakariya University, Multan, Pakistan 2004;15:41-43.

7. Hussain F, Islam M, Zaman A. Ethnobotanical profile of plants of Shawer Valley, District; Swat, Pakistan. Int. J. Biotech. 2004;3:301-307.

8. Nasir E, Ali S I. Flora of west Pakistan, Tech. Rep. 1190, Pakistan Agriculture Research Council, Islamabad, Pakistan; 1991-2001.

9. Nasir E, Ali S I. Flora of Pakistan, Nos. 1-193. Department of Botany, Karachi, University, Karachi. Pakistan Agricultural Research Council, Islamabad; 1970-1989.

10. Hazrat A, Shah J, Ali M, Iqbal, I. Medicinal value of Ranunculaceae of Dir valley. Pak. J. Bot. 2007;39(4): 1037-1044.

11. Jan G, Khan M A, Gul F, Ahmad M, Jan M, Zafar M. Ethnobotanical study of common weeds of Dir Kohistan valley, Khyber Pakhtoonkhwa, Pakistan. Pak. J. Weed Sci. Res. 2010;16(1): 81-88.

12. Qureshi S J, Khan M A. Ethnobotanical study of Kahuta from Rawalpidni district, Pakistan. Online J. Biol. Sci. 2001;I(1):27-30.

13. Zaidi Sh H. Existing indigenous medicinal plant resources of Pakistan and their prospects for utilization. PakJ. Forest 1998;48:5-9. 